UDC 336.71

JEL Classification: G21, G23

http://doi.org/10.21272/mmi.2018.4-27

Anzhela Kuznyetsova,

D.Sc., Professor, Banking University, Ukraine

Natalia Kozmuk,

Ph.D., Associate Professor, Banking University, Ukraine

Iryna Zherebylo,

Ph.D., Associate Professor, Banking University, Ukraine

Olena Sydorova,

Ph.D., Associate Professor, Banking University, Ukraine

Marta Zvarych,

Banking University, Ukraine

\title{
THE ESSENCE OF RETAIL AND DEVELOPMENT OF RETAIL BANKING INNOVATIVE MECHANISMS IN UKRAINE
}

Abstract. In the context of the dynamic development of retail banking business and competition growth, domestic banks are beginning to pay special attention to their customers, realizing that their success in the future will depend on a long-term close partnership with customers and on the level of satisfaction with the services provided. An important feature of modern banking taking into account form and technologies of cooperation is increasingly approaching of banking services for individuals to retail. Banks create a customer-oriented business model by offering specific services to specific groups of clients, trying to implement the principle of individual service for mass clientele. The ability of banks to respond to changes and the emergence of new consumer needs is increasing. Thus, the purpose of the article is to summarize and reflect the main theoretical aspects and development process of banking retail in Ukraine, to search for ways to optimize and increase the volume of banking products and services sales. It is determined that in order to achieve banking retail development banks need to keep deposits on their accounts by offering depositors more favourable conditions than other banks; to increase the resource base by attracting population deposits. A number of specific features of the banking retail sector are presented, such as: local assortment policy, which means the need of banking products portfolio adjustment, depending on the location of a banking institution; banking services complexity, which requires from clients a certain educational level; the need to support each client individual liquidity which makes possible to carry on further credit activities, ensure funds circulation; banking services individualization means taking into account the needs and interests of banking institution clients when forming a banking services package; banking services diversification what provides both an individual approach to the client and an expanding range of opportunities in choosing one or another action and perspective. During the scientific research the methods of logical generalization and scientific abstraction, the statistical method, the tabular method (for displaying of traditional banking services and banking retail features), the schematic method (for the main trends of online retailing and the benefits of innovative banking business technologies reflection) were used. The results of the study give grounds to assert that introduction of innovative measures in banking institutions activity which provide the latest approaches to banking retail policy development plays an important role in increasing the volume of banking products and services sales.

Keywords: retail, retail banking, commercial banks, innovations, deposit portfolio, innovative retail banking mechanism, banking service.

Introduction. Under the current conditions of the retail banking business, dynamic development and increasing of competition domestic banks are beginning to pay special attention to their consumers, realizing that success of banks in the future depends on the long-term close partnership with the clients and on the level of satisfaction with the services provided. Consequently, banks management bodies should update their approaches to the construction and implementation of effective partnership cooperation with active and potential clients in terms of their marketing and implementation activities. At

Cite as: Kuznyetsova, A., Kozmuk, N., Zherebylo, I., Sydorova, O., \& Zvarych, M. (2018). The Essence of Retail and Development of Retail Banking Innovative Mechanisms in Ukraine. Marketing and Management of Innovations, 4, 316-331. http://doi.org/10.21272/mmi.2018.4-27 
the present stage, such innovative approaches are implemented by the banking retail. Retail becomes a part of a united system called the "supply chain" and, in addition to the sale of goods, involves the organization of own production and sales of products under own brand, merchandising, the use of brands and trade-marketing technologies, the creation of its own logistics departments, as well as providing some subordinated services to customers (for example, goods delivery, orders acceptance, settlement with buyers on credit and debit cards, bank services, etc.). Taking into account current trends and expanding the range of services by enterprises and institutions, retail requires the development and introduction of new modern mechanisms and approaches.

In the modern managing process, the concept of "retail" is associated with the processes and mechanisms for goods and services sale to final consumers, so it is often identified with a set of mechanisms and technologies of retail trade. Continuous improvement of goods and services range, the use of modern information technology in retail sales requires retail mechanisms development. Modern retail is very different from a traditional retail trade, which was widespread several decades ago, according to the forms and spheres of development, and by industries and types of goods and services being sold. At the end of 1990s retail was used for certain types of goods usually in the field of trade, but with the transition to the post-industrial economy, retail was extended to the financial sector in general and to the banking sector in particular.

Literature review. An overview of modern theories and views of domestic and foreign scientists testifies that the unanimous interpretation of the notion of "retail" is not developed in the theory and practice. Today the concept of retail in the narrow sense is characterized by retail sales, retail trade, shops selling goods and services to the end user. In a broader sense, retail should be viewed not only as a trading point but also as a trade organization principle. According to P. Drucker, the definition of retail includes "any work with any buyer who can freely come and buy goods" [1]. B Santo proposed to define retail as "point of retail sale, store". In his opinion, the first example that fits the definition of retail is the well-known market and shops. Also, the scientist notes that the oldest form of retail is street-retail, or street trade"[2].

The definition formed by S. Fedosenko doesn't differ: "retailer is a company that deals with retail trade - whether it is a supermarket, a clothing store, a car dealership, a bank that sells services to private customers." The scientist considers retail as selling goods to end users. Unlike wholesale, retail trade sells goods not for resale, but for the final consumption by individuals, and the fact what form the retail trade has is not important at all: it can be sales by phone, on the Internet, personal sales, etc. [3].

Economists $\mathrm{O}$. Azaryan and Y. Antoniuk [4] view retail as "...an independent trade direction, which had been distinguished in antiquity from the merchant exchange, and later connected itself with an internal one-time exchange". Therefore, the authors substantiate the idea that this term appeared not at the present stage of development of trade relations but even in ancient times. The same opinion is shared by domestic scientists V. Apopiy and P. Balaban [5], who offer to interpret retail as a type of economic activity in the field of trade, covering sales of goods to the final consumer and providing him with trade services. T. Bilous and D. Kharinovich [6] have the same idea about retail, they define it as "the type of entrepreneurial activity in the field of trade, connected with the sale of goods directly to the consumer for personal, domestic, family, home use" and in its essence is a single-piece, or small-scale sales of goods for, as a rule, the final consumption. A. Bereza suggests considering retail as "...a commodity exchange process aimed at satisfying people needs through the free sale of goods and services representing value for them". Economists K. McConnell, S. Brue, and S. Flynn [7] interpret this notion as: "...resale (sale without modification) of new and used goods to the general public for personal consumption or home use, carried out by stores, department stores, tents, firms performing ordering by mail, street vendors, consumer cooperatives, firms, auctions, etc.»

Consequently, the concept of retail in the generalized context should be interpreted as a modern 
process of organization and technology of retail trade, taking into account the principles of interaction between the parties "seller-buyer".

The aim of the article. The aim of the article is to substantiate the theoretical principles of retail and banking retail, analysis of retail banking innovative mechanisms development in Ukraine.

Research methods. During the scientific research, the methods of logical generalization and scientific abstraction, the statistical method and tabular method (for displaying of traditional banking services and banking retail features), the schematic method (for the main trends of online retailing and the benefits of innovative banking business technologies distinction) were used.

Research results. In terms of the dynamic development of retail banking business and increased competition in the monetary sphere, domestic banks are beginning to pay significant attention to their customers, realizing that their success depends on a long-term close partnership with clients and on their level of satisfaction with the services provided by the bank and its activities in general. Therefore, retail firstly was exclusively considered as a term that is firmly established and widely used in trade, began to spread actively to the sphere of banking services sales.

In management the concept of "retail" is associated with the processes and mechanisms for goods and services sale to end users, therefore it is often identified with a set of mechanisms and technologies for retail sales. However, modern retail is significantly different from the traditional retail trade, which has been widespread several decades ago, according to the forms and spheres of development, as well as to the branches of development and types of goods and services being sold. Under the conditions of existing sales technologies and goods and services range improvement, as well as the use of modern information technologies, retail mechanisms are constantly evolving and improving. A specific feature of retail is the large variety of goods and services offered in one place, which reduces the cost of servicing each client and improves competitiveness.

Modern retail uses the following retail technologies [1]:

- placement of retail trade points in accordance with certain rules of location;

- proposal of grouped goods/services assortment of constant demand;

- application of the corresponding equipment;

- application of marketing technologies;

- minimum of sales staff;

- application of customer self-service;

- automation of accounting;

- optimization of logistics, trading space, etc.

The use of listed retail technologies allows selling of goods in large volumes, which can be compared to the volumes of wholesale [1]. A fairly used type of modern retail is the network retail - a network of oneformat (rarely multi-format) stores, united by one owner, a single logistics system, procurement, and commodity policies. All this allows to reduce costs, and therefore to offer a buyer much lower prices of products than in non-network retail outlets. Network retail attracts a large number of consumers and receives more profit at the expense of turnover by low prices and constant assortment availability, by the accessibility of retail outlets [2]. The retailer receives the main revenue for a trade margin on the goods retailed. However, this is not the only source of his income. There are additional services paid by-products suppliers, the income of which is also received by retail. An ability to supply a product in retail, the opportunity to put the goods on the desired for the supplier "shelf", payment for commercial marketing services - all this is "sold" by retailers to products suppliers as a marketing service. In this way, retailers earn on discounts, advertising, selling (leasing) of retail space for non-core products [1].

The key to retail is publicity and accessibility because any person can make a purchase or receive a service. In order to reduce the cost of customer service, retail reduces the service personnel quantity in an effort to meet the needs of maximum customers by introducing self-service in supermarkets or by ATMs 
and payment terminals installation. Retail offers consumers a wide range of products/services that can be purchased in one place.

A few years ago, within the diversity of innovative technologies, the retail used cash automation, logistics, warehouse accounting, and data storage technologies, what allowed to improve the sales network management. Today's rigorous competition forces to look for new ways of customers attraction, marketing tools and IT solutions, such as business analysis, "clouds", omnichannel services and other innovative technologies integration becomes relevant. These concepts are only coming into retailer's use [3]. The avalanche-like growth of information in the world is one of the key trends noted by experts. At the level of a trading company, it means constantly updating data on sales, goods, prices, information for consumers profiling and analysing their behaviour. For companies, the gigantic amount of data is both a great complexity deal and enormous opportunities at the same time. The difficulty is that without professional business analysis systems it's virtually impossible to understand the data. But with the help of modern BI (Business Intelligence) solutions, forecasts of product movements may be formed, loyalty programs may be developed, and demand may be stimulated.

Despite the fact that most BI-systems from well-known world leaders (such as Oracle, SAP, IBM, Microsoft, etc.) have been available on the domestic market for a long time, not every retailer uses these opportunities today. However, the retail is being improved gradually. For example, thanks to the implementation of SAP BW on SAP HANA in "M. Video" the process of creating corporate reporting in various sections has been significantly simplified. Thanks to the model for calculating the need for the goods release from distribution centres, the retailer can assess the correctness of settings in the planning systems, and if it is necessary, he may respond promptly to the situation [3].

Online sales account for only a few per cents of all retail sales today. Since traditional sales brought the business the required amount of revenue, retailers did not develop online channels for a long time. But today there is a reverse trend. Business systems that can profile the buyer, calculate his behaviour, and build customized offers are needed for competent Internet commerce. They should be able to work from the manufacturer warehouse with the related software of vendors. And integration with social networks allows to offer a birthday discount, analyse a list of interests and based on it make a purchase wish list automatically [3]. The omnichannel assumes that a customer can place an order at any point in the world, using the Internet or cell phone, to pay with any convenient method (credit card, cash, checks, bonuses, Web money) and pick up an order in a convenient place. In this case, the buyer receives after-sales service at his place of accommodation (for example, the order was made via the website, confirmed by SMS, and received in a regular store or special cell). Toda every other resident in Japan buys (even an eggs package) through special machines with the omnichannel, booking a cell where it is convenient to pick up an order. The main task of the omnichannel is to get rid of the intermediary between the service provider and the end customer, that is to abandon the warehouses, etc. However complete automation of the whole business is required for the correct operation of this service, in particular, a built-in online commerce system, a perfectly adjusted process of inventory management and goods distribution. The success of retail business automation projects directly depends on the IT team professional experience and retail specifics understanding [3]. In order for goods arrival in stores on time and in good condition there is specialized solutions, in particular, the Transportation management system. These are tools specifically designed based on the needs and characteristics of logistics processes. With their help the most optimal scheme of transportation may be chosen, movement of goods may be tracked, and transport plan may be adjusted, even records of all costs incurred in transport services provision and restrictions in cargo terminals operation may be kept.

RFID technologies (Radio frequency identification) allow identifying objects with radio frequency labels and controlling their movement, thereby accelerating product accounting and guaranteeing its protection against theft. "Smart" carts with built-in scanners and touchscreen tablets will appear soon in supermarkets 
in order to control the choice of products. For example, by synchronizing a shopping list through a mobile application on a smartphone with GPS and NFC, it will be easier for a buyer to navigate among products and shelves [3]. Another example of interactive solutions is the technology of "augmented reality" or "smart mirrors" of the virtual fitting room. The camcorder scans the external parameters of a person, and the system of complemented reality offers three-dimensional models of clothing, fitted under the figure. The technology allows determining what suits the buyer, significantly reducing the time for fitting and increasing the throughput capacity of the cabins [8].

Advertising on paper posters and information boards is actively replaced by interactive video advertising on LED stands, which allows to "reach" the target audience in the right place and at the right time. In this case, already created and accessible solutions, integrated with Digital Signage systems can not only bring information to the consumer but also provide feedback. The easiest example is an analysis of the audience with the ability to determine how many people are reading, for example, the details of the discount, and how many just draw attention to the picture, what is age, sex, the social status of these potential buyers, etc. In order to start collecting such information, it is sufficient to install a digital camera next to the video panel and analyse the human flow using special software [8].

Retail accumulates a large amount of data, that is information from cash checks, appealing to loyalty cards, visitors' counters in stores, data on warehouses load, and so on. In order for this data to be processed promptly and to obtain conclusions that are useful for business, it has to be stored somewhere. Some retailers build their own data processing centres (DPC), others lease computing power and equipment. At the same time, equipment leasing can save up to $50 \%$ of maintenance costs for IT in the short run [3]. Cloud computing is another business model, in which the company pays only really consumed computing resources. It provides all IT processes automation, allows to reduce not only capital costs but also operational costs by optimizing the staff of the IT department. Analysts predict that the business benefits of "clouds" in the near future will be available for small and medium-sized businesses. Meanwhile, big retailers already use "cloud" technologies. For example, in the past year, CROC created accounting documentation archive "M. Video" on the basis of the domestic virtual data centre. Overhead and shipping documents came from all over the country, after that, they were digitized and merged into catalogues. Now the retailer operatively receives operational data directly from the "cloud" [4].

The boom of robotics has the ability to change the principles of retailers and buyer's interaction, although it is not quite clear when and how much. At the moment, the gradual approach to the future retail with robotic warehouses, integrated corporate information systems, and sales robots is continuing. For example, there are already information guides robots in retail. Built-in GPS sensors and the ability to control through mobile communications make them universal assistants, intelligent consultants and promoters that attract customers' attention. Such robots can be used practically in any public places, including shopping centres and exhibitions [3]. There is no universal approach to calculating the volume of IT investments. Some companies are just beginning to automate business processes, others are already in the process of optimizing IT budgets since in previous years they actively invested in infrastructure and now expect returns on investments. Each retail network, thanks to its capabilities and the notion of effective business management, is master's in information technologies. But there is a general trend that development is possible only with information technologies application. This means that the retailer's dictionary will be replenished with new IT terms, and the one who learns to navigate their diversity more quickly and choose the best solutions for themselves is going to have a competitive advantage [8].

The IT solutions world is constantly changing. Each retailer masters them by virtue of his possibilities. But the competitive advantage will be for those who learn to orient themselves more quickly in these decisions and choose the most appropriate ones for themselves [8]. To sum up, following 5 main trends of online retail may be submitted (Figure 1). 


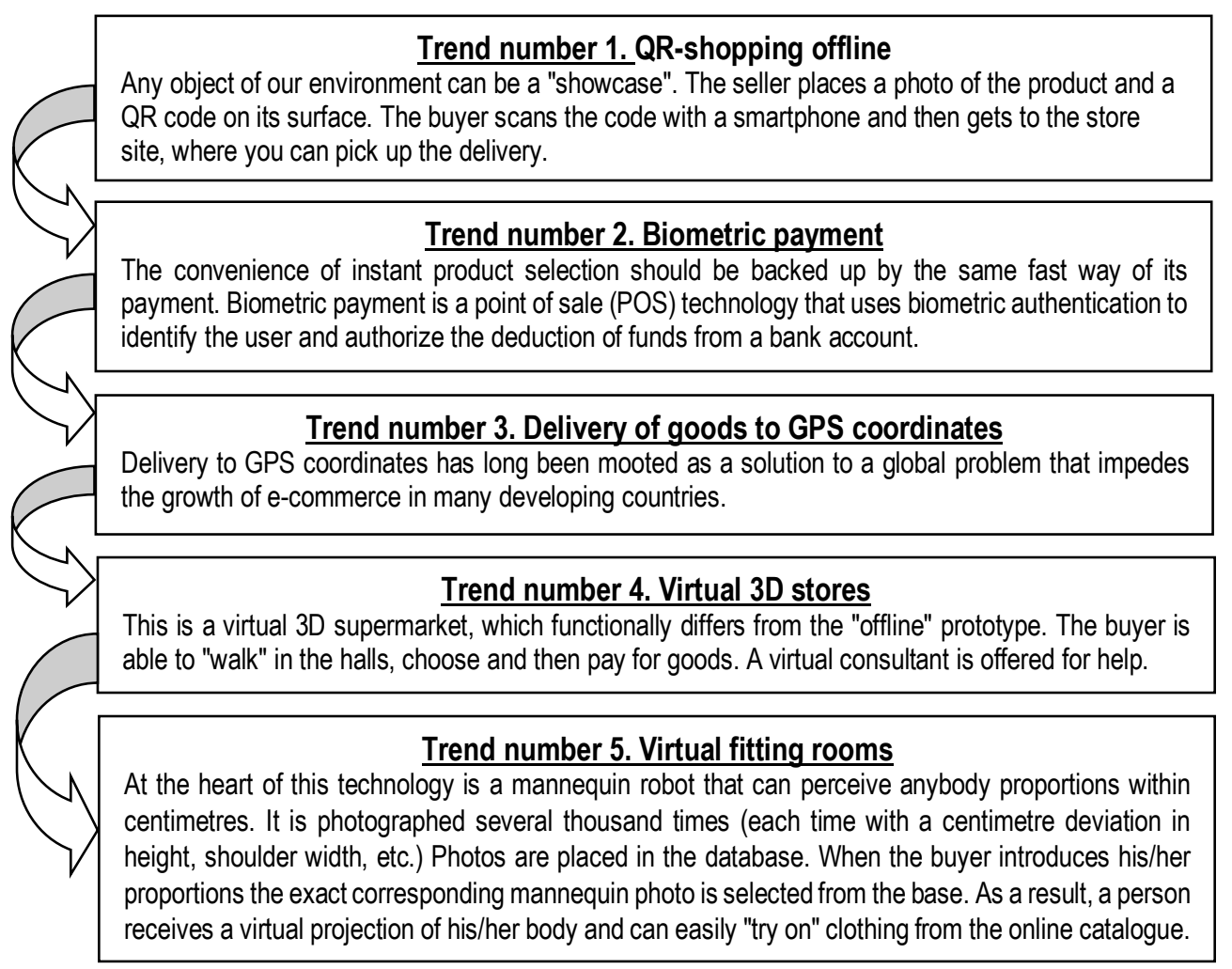

Figure 1 - The main trends in online retail

\section{Sources: [9]}

It is not sufficient to transfer mechanically foundations, mechanisms and principles of commercial and industrial retail to the financial or banking sector. There is a need to adapt already developed knowledge and experience in the trade and industry to the specifics and features of retail banking in the banking industry. Today a significant number of banks with stable positions in the field of retail banking services consider this business as a source of stable income and a niche where it is possible to "hide" during difficult times. Taking into account the unrivalled ness of the research topic and the underdevelopment in the proposed definitions of the "banking retail" category, we propose the following definition: banking retail is a complex of retail banking services and products focused on a strategy of improved interaction between the bank and customers for the consumption development.

Consequently, we can consider the "banking retail" concept as a process of creating and implementing a list of banking products and services that will be accessible, comprehensive and understandable to the maximum consumers' range who intend to obtain them. A banking product and service that needs development and competitiveness provision is considered as an object of bank retail. The main tasks of retail banking are:

- analysis of the place for a bank affiliate opening in a certain format;

- an estimate of the location for an ATM or a terminal placing for better payback.

The reason for the active familiarization with the retail market by banks is due to the capital requirements set by the Basel II Agreement coming into effect. Possible risks on the market can encourage 
corporate banks to shift their strategic emphasis from providing loans to companies and investing in private capital to more stable service for individuals. With the purpose of new markets active development, banks are now striving to consolidate capital by retail banks purchase, what allows them to expand the range of retail products, to make a quick expansion into regional markets, as well as to enter new markets. According to Basel II banks also seek to balance the least sustainable business activities (such as investment activities, trust management) at the expense of more stable flows of income from servicing individuals. Modern banking retail, first of all, is a spectrum of technologies (from business process organization to the channels of products delivery to population); therefore, banking business management must be distinguished by the responsiveness of the reaction to market changes and the continuous search for new target landmarks. A key role in this process is the change in the qualitative composition of banking services potential customers. The young (more competent and active) generation of consumers attracts more attention to desires and needs. Such a category of potential clients wants to spend as little time and resources as possible and strives to receive vivid individualized services [2]. The main advantages of innovative banking business technologies include:

- better service of individual clients;

- risks reduction associated with retail banking services provision;

- the increase of bank performance with every client;

- the increase of retail activities profitability in general [2].

There is a change of standard banking services to fully automated customer service or through ATMs. The result is an increase in the transactions volume carried out through electronic information banking systems. Expanding the range of alternative channels and retail banks is seen as a necessary step towards creating a virtual bank. The financial institution functioning involves not just the rejection of traditional bank branches network standard sales of banking products and transition to virtual channels. Virtual bank means complete its restructuring and radical change in the forms of interaction with the client [1]. The development of retail banking dictates the market, and this is a must for the banking sector and physical consumers of banking products. Among such products we can distinguish:

- lending to current needs;

- placement of money in deposit accounts;

- payment cards service;

- private banking;

- organization of pension services;

- organization of lending;

- asset management;

- financial and property consulting;

- exchange transactions;

- realization of money transfers in national and foreign currencies;

- cash payments;

- opening and maintenance of current accounts of individuals, including card accounts;

- credit card accounts servicing;

- consumer lending for various types of security and unsecured loans;

- individual bank accounts leasing;

- financial advising and information;

- sale and acceptance of bank metals deposits;

- mortgage lending in the primary and secondary residential real estate markets;

- trust management of the property;

- telephone and home banking; 
- distance counselling centres, such as "hotline";

- consulting services "personal manager";

- registered and traveller's checks issuance;

- payment for goods and services of legal entities;

- investment services (shares, bonds, funds for construction financing, etc.);

- acceptance of utility bills and others.

The product line formation of banking retail is determined by the results of a deep and comprehensive study of the population needs in financial services and includes, first of all, the creation of the integrated product that maximally meet these needs. The parameters and the essence of these products vary according to changing market conditions and customer needs. At the same time, retail banking networks are organized in such a way as to enable the provision of any of the existing services in each branch (the trading floor or the terminal of the bank). Bank branches must be in close proximity to the consumer, requiring the operation of their large number and the network's formation, aimed at comprehensive services. Regarding the current state of retail banking in Ukraine, retail client loan portfolio decreased by $10 \%$ over the year 2016 and amounted to UAH 164.98 million. Recognition of several banking institutions insolvency, which had substantive volumes of loan portfolios, including retail, made a significant influence on the dynamics of this indicator.

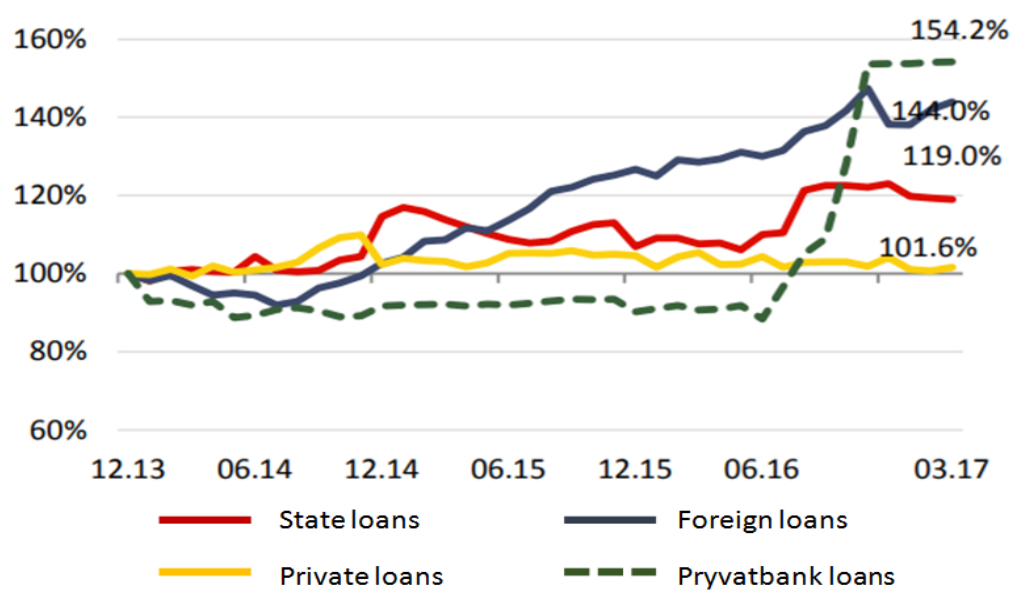

Figure 2 - Loans granted to legal entities, $\%$.

Sources: the figure is compiled on the basis of statistical data of the National Bank of Ukraine [10]. 
A. Kuznyetsova, N. Kozmuk, I. Zherebylo, O. Sydorova, M. Zvarych. The Essence of Retail and Development of Retail Banking Innovative Mechanisms in Ukraine

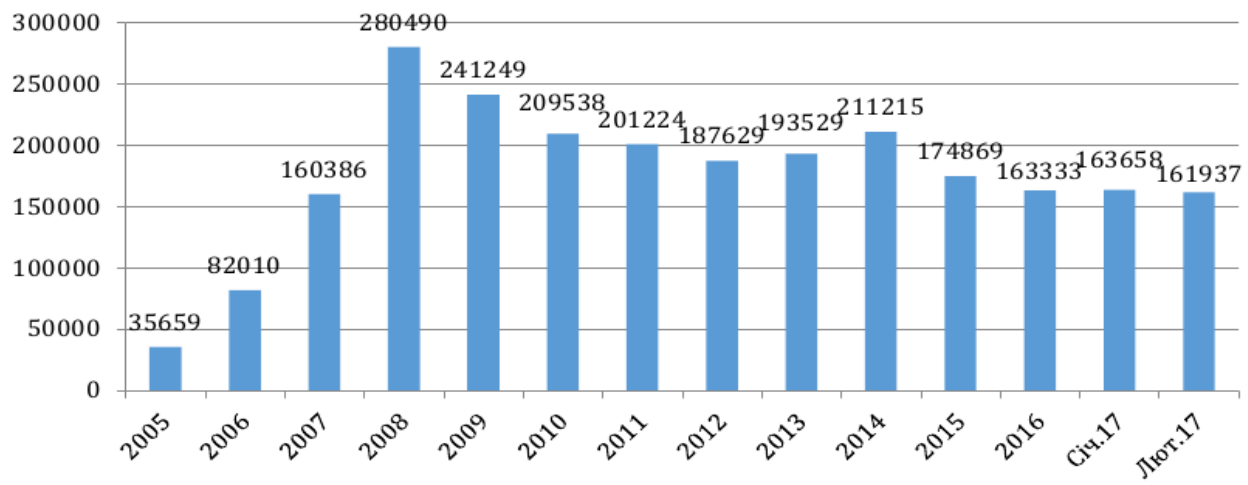

Figure 3 - Loans granted to individuals, million UAH

Sources: the figure is compiled on the basis of statistical data of the National Bank of Ukraine [10].

About $57 \%$ of the client's portfolio is located in the northern region of the country (Kyiv oblast and Kyiv, as well as Zhytomyr, Sumy and Chernihiv oblasts) (Figure 4).

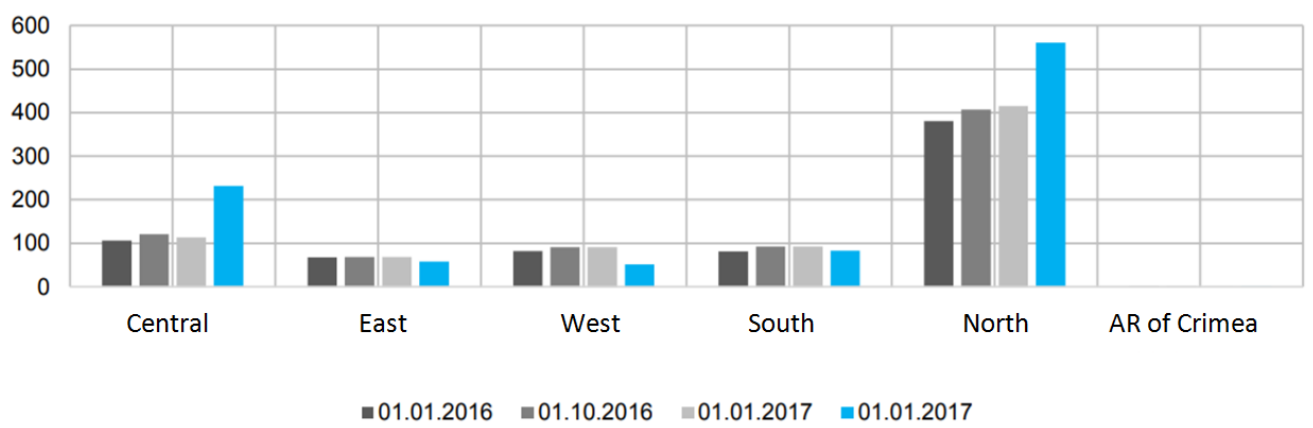

Figure 4 - Client's loan portfolio in a regional section as of 01.01.2017, billions UAH

Sources: the figure is compiled on the basis of statistical data of the National Bank of Ukraine [10].

According to the results of 2016, the average interest rate on loans granted to individuals in the national currency amounted to $30.7 \%$ (31.6\% in 2015) and $4.9 \%$ in foreign currency (4.0\% in 2015). The conducted analysis shows that raising interest rates on loans, fluctuations in the exchange rate led to a certain slowdown in the lending process. This led to loans granted to legal entities and individuals' reduction, a decrease of satisfaction with banking services and a slowdown in the banking retail development. Today banks' lending services for individuals can be divided into three distinct categories that are related to the purpose of services provision, in particular: consumer lending; car loan; housing loan. The main component of the retail client loan portfolio is consumer loans (including cash loans) (Table 1). Analysis of the data from table 1 confirms that since 2009 there has been a decline in the volume of consumer loans provided: the decrease was $26 \%$ or 48975.00 million UAH in 2009. Nevertheless, the share of consumer loans in the total volume of bank loans granted to individuals remained relatively stable - an average of $63 \%$ for the period of $2009-2016$. 
A. Kuznyetsova, N. Kozmuk, I. Zherebylo, O. Sydorova, M. Zvarych. The Essence of Retail and Development of Retail Banking Innovative Mechanisms in Ukraine

Table 1 - Target loans granted to individuals, 2009-2016 years

\begin{tabular}{|c|c|c|c|c|c|c|c|c|c|}
\hline \multirow[t]{2}{*}{ Period } & \multirow[t]{2}{*}{$\begin{array}{c}\text { Total, mln } \\
\text { UAH }\end{array}$} & \multicolumn{2}{|c|}{ Consumer loans } & \multicolumn{2}{|c|}{$\begin{array}{l}\text { Loans on } \\
\text { purchase, } \\
\text { construction and } \\
\text { reconstruction of } \\
\text { real estate }\end{array}$} & \multicolumn{2}{|c|}{ Other loans } & \multicolumn{2}{|c|}{ Mortgage loans } \\
\hline & & mln UAH & $\%$ & mln UAH & $\%$ & mln UAH. & $\%$ & mln UAH & $\%$ \\
\hline 01.01 .2009 & 280490 & 186008 & 66,3 & 88352 & 31,5 & 6050 & 2,2 & 143416 & 51,1 \\
\hline 01.01 .2010 & 241249 & 137113 & 56,8 & 98792 & 41,0 & 5343 & 2,2 & 132757 & 55,0 \\
\hline 01.01 .2011 & 209538 & 122942 & 58,7 & 81953 & 39,1 & 4643 & 2,2 & 110725 & 52,8 \\
\hline 01.01 .2012 & 201224 & 126192 & 62,7 & 70447 & 35,0 & 4585 & 2,3 & 97431 & 48,4 \\
\hline 01.01 .2013 & 187629 & 125011 & 66,6 & 58427 & 31,1 & 4191 & 2,3 & 63158 & 33,7 \\
\hline 01.01 .2014 & 193529 & 137346 & 71,0 & 51447 & 26,6 & 4736 & 2,4 & 56270 & 29,1 \\
\hline 01.01 .2015 & 211215 & 135094 & 64,0 & 71803 & 34,0 & 4318 & 2,0 & 72156 & 34,2 \\
\hline 01.01 .2016 & 174869 & 104879 & 60,0 & 66169 & 37,8 & 3821 & 2,2 & 60215 & 34,4 \\
\hline 01.01 .2017 & 163333 & 101528 & 62,2 & 58549 & 35,9 & 3255 & 2,0 & 60264 & 36,9 \\
\hline
\end{tabular}

Sources: table is compiled on the basis of statistical data of the National Bank of Ukraine [10].

This trend could lead to a new wave of intensification of consumer lending, but it did not survive by the end of 2011. The volume of loans to households at the end of 2012 amounted to UAH 187.6 billion, which was less than in 2008. Thus, lending to population was not restored by 2013 to pre-crisis levels. During 2011-2014 only a segment of small loans was actively developing in the consumer credit market - cash loans, credit cards, and consumer goods loans. They ensured the revival of this segment, what was evidenced by some growth - about $10 \%$, but the restoration of pre-crisis volumes of lending was hampered by political and economic instability in the country, and already during 2015-2016 there was a decrease in its volumes again. Based on these data provided the main problems of bank consumer lending are:

- inflation processes development;

- real wages reduction;

- national monetary unit devaluation;

- low solvency of individuals;

- high cost of consumer loans;

- insufficient analysis of individual borrowers' solvency by credit institutions', which leads to credit risks increase and non-repayment of bank consumer loans.

The volume of mortgage loans granted to individuals amounted to $37 \%$ of the retail loan portfolio as of 01.01.2017. In general, the low growth rates of mortgage lending are due to the rather slow recovery of the construction industry, the limited and high cost of the long-term resource, as well as low solvent population's demand for long-term lending. Development and functioning of banking retail, innovative solutions and products directly depend on the activity of using payment cards, which in turn depends on the existing system and the network of such payment means usage. It should be noted that the market for payment cards also continues to grow (Figure 5). While analysing the growth dynamics of payment cardholders, the number of payment cards in circulation and active payment cards, it should be noted that from 2002 to 2009 the number of issued cards exceeded the number of such card's holders, and these cards were actively used. This is due to the target cards issue for servicing banking products such as salaries, deposits or current accounts.

However, in 2012 with a slight change in the number of cardholders (37-50 million people), the number of issued cards grew sharply to 69.826 million. As for active cards, its number dropped sharply compared to 2008 (41.2 mln. UAH) and in 2013 it amounted to 35.6 million UAH. 
A. Kuznyetsova, N. Kozmuk, I. Zherebylo, O. Sydorova, M. Zvarych. The Essence of Retail and Development of Retail Banking Innovative Mechanisms in Ukraine

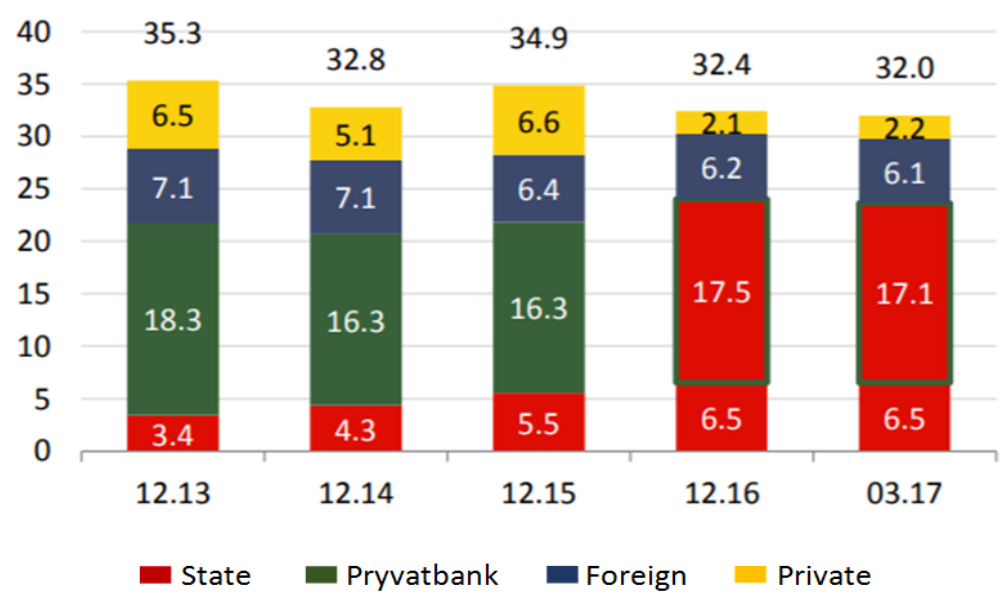

Figure $\mathbf{5}$ - Number of active payment cards by groups of issuing banks, million units

Sources: the figure is compiled on the basis of statistical data of the National Bank of Ukraine [10].

It should be noted that the number of active payment cards in 2016 slightly decreased compared to 2015 due to mass cards issuance for a variety of banking products that were provided to citizens in the package of a product before the concluded deals. However, in the first quarter of 2017, this indicator increased significantly and amounted to 32 million units. The number of ATMs is also constantly increasing (Figure 6) that indicates the demand for card products in Ukraine.

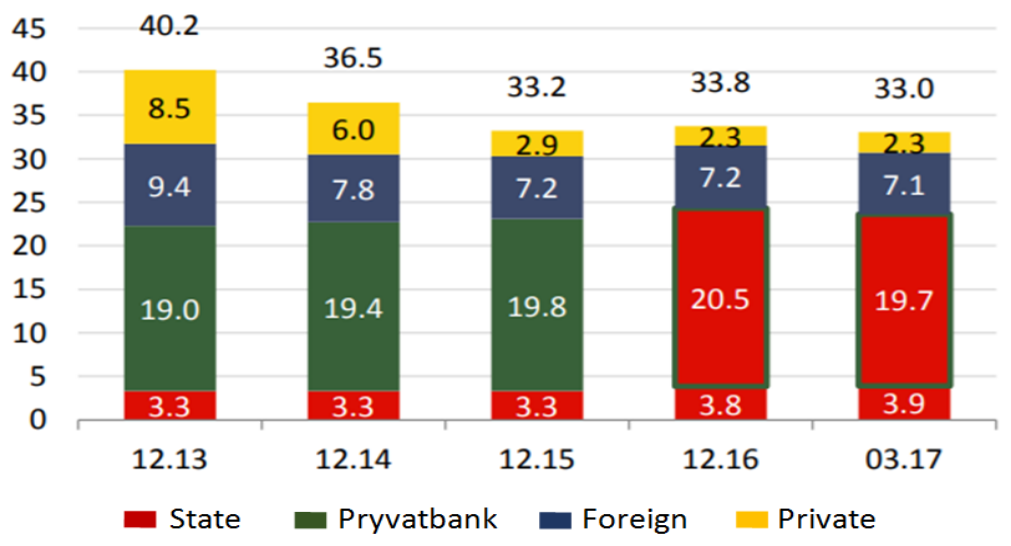

Figure 6 - Number of commercial banks ATMs, thousand units

Sources: the figure is compiled on the basis of statistical data of the National Bank of Ukraine [10].

One of the priority directions of banks cash servicing is the comprehensive customer service, which consists of a set of basic banking services for servicing current accounts in national and foreign currencies, payments and cash operations. Banks generally try to reduce operational costs by transferring them to equipment, a network of partners, or remote internet service channels. Thus, there is a division: services provided with advanced computer technologies without the participation of bank employees, and services 
A. Kuznyetsova, N. Kozmuk, I. Zherebylo, O. Sydorova, M. Zvarych. The Essence of Retail and Development of Retail Banking Innovative Mechanisms in Ukraine

requiring a personal contact between a banker and a client (VIP-service) [11, p. 66]. The number of banks that provide services over the Internet is increasing (Table 2).

Table 2 - Internet banking services at domestic commercial banks

\begin{tabular}{|c|c|l|}
\hline Bank name & Internet banking system & \multicolumn{1}{|c|}{ Opportunities } \\
\hline Privatbank & Privat24 & $\begin{array}{l}\text { Statements review; deposit registration; currency } \\
\text { exchange; any types of payments; mobile phone } \\
\text { replenishment; additional services for payment cards }\end{array}$ \\
\hline Ukreximbank & Financial portal & Statements review; any types of payments \\
\hline Ukrsibbank & Account management & Statements review; any types of payments \\
\hline Ukrsotsbank & Internet Banking & $\begin{array}{l}\text { Statements review; deposit registration; any types of } \\
\text { payments; mobile phone replenishment }\end{array}$ \\
\hline Prominvestbank & PIB-ONLINE & Statements review; currency exchange \\
\hline Alfa-bank & My Alfa-Bank & $\begin{array}{l}\text { Statements review; any types of payments; mobile } \\
\text { phone replenishment }\end{array}$ \\
\hline OTP bank & OTPdirekt & $\begin{array}{l}\text { Statements review; any types of payments; } \\
\text { replenishment and withdrawal of savings account }\end{array}$ \\
\hline
\end{tabular}

Sources: [9]

The main banks' motivation for Internet banking implementation is increasing competitiveness. First of all, the advantage of Internet banking is a significant cost minimization, since the cost of providing online banking services is significantly lower than the same indicator for traditional financial service mechanisms. Financial services are suitable for "remotely" provision because it does not require the physical presence of the service provider and it is not accompanied by the movement of tangible assets, what ensures the relevance and modernity of the Internet banking introduction.

Taking into account current trends, mechanisms for goods, works and services sale banks should take into consideration all the requirements and challenges of a market economy, as well as the influence of external factors and the risks associated with them. The sale of banking products is not an exception and requires significant changes and innovations that will ensure the competitive performance of a particular banking institution in the financial and banking market. At the same time, an effective mechanism of banking retail cannot be ensured only at the level of operational management. Without a well-thought-out strategy and an effective mechanism for its implementation, organizational and economic innovations are turning into separate measures for improving the timely implementation of the banking product, which is sometimes more harmful due to the fact that they are not related to the deep processes of changing banking technologies and financial markets.

Banks innovations relate to all spheres of their operation and are embodied in new products and services, business processes and business model's improvement, organizational transformations and modifications of marketing methods. "Innovative thinking" aimed at finding an effective implementation of creative ideas begins to penetrate all bank's activities. Taking into account the scale and variety of innovation changes the significant influence of its implementation success degree on financial results, competitive position, banks reputation, the strategic management of these processes becomes objectively necessary, what allows using innovations as an instrument of financial and credit institutions adaptation to the environment, which is changing unpredictably.

Thus, banking retail becomes an integral part of a strategic management system, and in addition to the banking products and services sale, provides an effective implementation policy organization that ensures the keeping a client base accounting and an individual approach to each client. And taking into 
account current trends and expanding the range of services by enterprises and institutions, retail requires the development and introduction of new modern mechanisms and approaches. We suggest considering the concept of "retail banking innovative mechanism" as a set of innovative methods and principles used in the bank's innovation policy during business processes and business model's formation that provide an effective implementation policy.

The retail banking innovative mechanism must be considered as an integral part of the entire bank, along with elements such as the subsystem of investment development, the subsystem of risk management, the subsystem of asset and liability management, etc. The innovative mechanism includes planning and budgeting of innovation development, staff incentives and motivation, control over innovations implementation, innovation process information provision. The most important component of the overall innovation mechanism is the organizational and economic development subsystem. It has such a feature: on the one hand, organizational and economic conditions is a prerequisite for the innovation's implementation and on the other hand, the organizational and economic component is a separate object of innovation politics. Among the functions of the retail banking innovative mechanism we propose to highlight the following ones: informational function aimed at informing a wide range of banking products and services consumers; the provisional function which aims to enrich and develop both the activity of households and the economy of the state as a whole by providing bank lending, paying interest on deposits; social function, providing customer orientation and individual approach.

In today's conditions, the key to successful bank operation is the development and implementation of innovative mechanisms that focus on creating the highest consumer value for customers, allowing to provide and maintain competitive advantages in the long run. We can highlight the following modern innovations offered by commercial banks:

1. Measure customer satisfaction (Loyalty Programs), characterized by collecting information from customers: determining the degree of customer satisfaction and identifying their basic needs.

2. Customer Relationship Management (CRM-technology), what involves gathering information to better understand customer needs.

3. Key competency characterized by investing in special skills or technologies that create a unique value for customers.

4. Benchmarking, which involves comparing costs and productivity with internal and external reference points. Implementation of best practices to achieve the goals.

5. Balanced performance indicators system, which includes the mission translation and tracking the planned activities results.

6. Process-oriented management, which is characterized by tracking the overall and indirect costs of all processes, taking into account specific products and customers, the opportunity to allocate costs more accurately and make optimal solutions.

7. Business processes re-engineering that involves radical changes in key business processes in order to achieve a substantial improvement in banking product quality and reducing time waste.

Taking into account the wide range of innovative methods, principles and functions involved in the bank's innovation policy during the forming its business models and business processes, we consider that depending on the strategy chosen by the bank and defined guidelines, several types of innovative retail banking mechanisms can be distinguished, namely:

1. Banking retail innovative mechanism aimed at creating an effective system for banking product selling.

2. Banking retail innovative mechanism focused on creating the maximum consumer value for the client.

3. Banking retail innovative mechanism focused on creating a system of interaction "client-bank", which will ensure a close and effective connection between these components. 
Proposed innovative retail banking mechanisms should ensure the fulfilment of specific tasks (Figure 7).

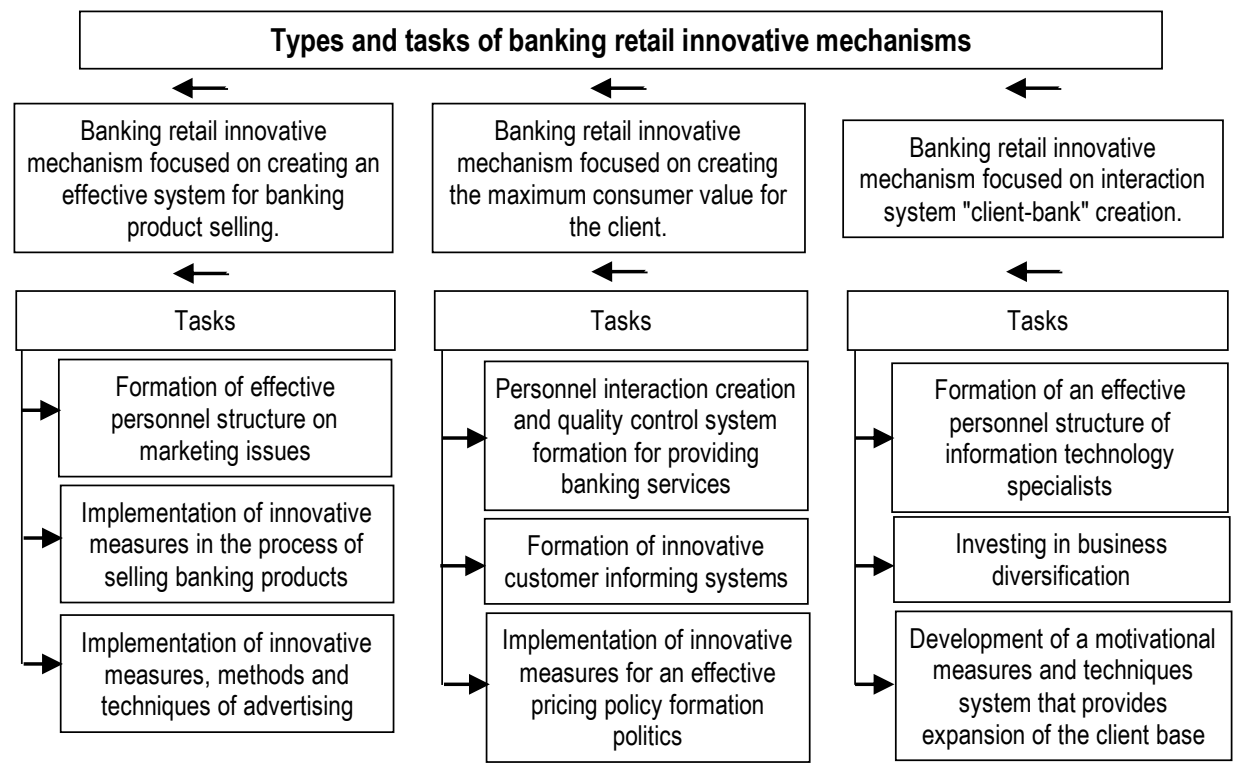

Figure 7 - The main tasks of retail banking innovative mechanisms

Sources: authors' own development

The most important organizational and economic innovation in the field of sales should be the expansion of direct sales practice. The value of direct sales in banking practice will increase due to the following reasons: the network of banking products sale points expansion and increase in the number of clients who have the desire and opportunities for direct contact with the bank managers in order to purchase the target package of services ("unique trade offer - UTO"); gradual transition from passive forms of interaction with the client to the system of human relations management. The purpose of such innovative technology is not a single agreement conclusion, but long-term relationships construction with the client increased customers' confidence in personnel management and individual requirements accounting [13].

The internal business procedures construction during direct sales organization is considered as an integral part of an integrated approach implementation. The optimal construction of planning, budgeting, controlling and direct sales motivation processes is designed to ensure that the profitability and cost of each service are recorded on the consolidation basis of the responsibility areas. In the conceptual construction of traditional banking management systems, the client was considered only as an environmental element that is not integrated into business processes. The purport of such arrangement systems of bank management, determined by the business processes directly to optimize only the internal bank activities itself, is now outdated. Many units of banks front-offices working with clients are separated from each other [14]. The lack of a single integrated approach affects the work effectiveness: a bank loses the ability to actively increase sales and attract new customers.

Conclusions. The need for strategic banking innovations introduction is caused by promising forecasts of credit institutions financial activity in the banking market, as well as the need to strengthen and expand the bank positions in the financial market sectors. In view of the above, the main objective of 
introducing banking innovations is to increase the competitiveness of individual products and services, as well as the entire bank organizational structure in the future. Thus, the innovative mechanism of banking retail must be considered as an integral part of the entire bank, along with elements such as the subsystem of investment development, the subsystem of risk management, the subsystem of asset and liabilities management, etc. New banking technologies, organizational and economic decisions and services provided to customers, as well as other innovations that are useful for the external environment (for example, universal methods for other banks, information, the growth of reputation, business activity) must become a result of the innovation complex operation in the bank.

\section{References}

1. Sait vydavnychoho domu "ImidzhMedia" [The website of the publishing house "ImageMedia"]. http://www.trademanagement.ru Retrieved from http://www.trademanagement.ru/termin/57/ [in Ukrainian].

2. Suchasni IT technologii v ryteili [Modern IT technologies in retail]. http:///xitex.net Retrieved from http://xitex.net/suchasni-ittehnologiyi-v-ritejli.htm [in Ukrainian].

3. IT technologii v ryteili [IT technologies in retail]. http://datawiz.io Retrieved from http://datawiz.io/ru/blogs/ [in Ukrainian].

4. Azaryan O.M., Antonyuk Ya.M., Apopiy V.V. and others (2007). Vnutrishnia torhivlia: rehionalni aspekty rozvytku [Domestic trade: regional aspects of development]. Donetsk: DonNUET [in Ukrainian].

5. Antonyuk Y.M., Apopiy V.V., Mitsenko N.G. and others.; under ed. of Apopiy V.V., Balaban P.Yu. (2014). Vnutrishnia torhivlia Ukrainy: problem I perspektyvy rozvytku [Domestic trade of ukraine: problems and prospects of development]. Lviv: "Novyi svit-2000"

6. Bilous T.D., Kharynovych D.O. Tendentsii rozvytku rozdribnyh torhovelnyh merezh [Trends in the development of retail chains]. http://intkonf.org Retrieved from http://intkonf.org/index.php?s=\%EF\%EE\%EA\%E0\%E7\%ED\%25\&paged=78 [in Ukrainian] .

7. McConnell C., Brue S., Flynn S. Essentials of Economics. McGraw-Hill Higher Education, 2013. - 570 p.

8. Maibutnie onlain-ryteila: 5 holovnyh trendiv ryteila [Future of online retail: 5 main retail trends]. http://www.therunet.com Retrieved from http://www.therunet.com /articles/1260-buduschee-onlayn-riteyla-5-glavnyh-trendov [in Russian].

9. Demchenko A.M. (2014). Suchasnyi stan bankivskoho ryteilu v Ukraini [The current state of bank retail in Ukraine]. Finansovyi prostir - Financial space, 3 (15), 48-52 [in Ukrainian].

10. Ofitsiynyi veb-sait Natsionalnoho banku Ukrainy [Official website of the National Bank of Ukraine]. https://bank.gov.ua Retrieved from https://bank.gov.ua/control/uk/publish/article?art_id=34661442\&cat_id=34798593

11. Sydorova O.V., Demchenko A.M. (2017). Rynok bankivskyh posluh v Ukraini ta mechanizmy yoho doslidzhennia [Market of banking services in Ukraine and mechanisms for its research]. http://fkd.org.ua Retrieved from http://fkd.org.ua/article/download/121172/116976

12. Borysova N.K. (2010). Prakticheskie voprosy razrabotki korporativnykh standartov riteila [Practical issues in developing retail corporate standards]. Bankovskiy riteil-Banking retail, 5 [in Russian].

13. Zolotova Ye.A. (2007). Sovremennaya situatsyia na rynke potrebitelskoho kreditovania v Stavropolskom krae [The current situation in the consumer lending market in the Stavropol Territory]. Finansy i kredit - Finance and credit, 32 (272), 23-30

14. PLP Law Group. Retrieved from http://plp.kiev.ua [in Ukrainian].

A. Я. Кузнєцова, д.е.н., професор, Університет банківської справи (Україна);

H. I. Козьмук, к.е.н., доцент, Університет банківської справи (Україна);

I. В. Жеребило, к.ф.н., доцент, Університет банківської справи (Україна);

O. B. Сидорова, к.е.н., доцент, Університет банківської справи (Україна);

M. C. Зварич, Університет банківської справи (Україна).

Сутність ритейлу та розвиток інноваційних механізмів банківського ритейлу в Україні

В умовах динамічного розвитку роздрібного банківського бізнесу та зростання конкуренції, вітчизняні банки починають приділяти особливу увагу власним споживачам, розуміючи, що успішність діяльності банків у майбутньому залежатиме від довготривалих тісних партнерських відносин з клієнтами та від рівня їхньої задоволеності наданими послугами. Важливою характерною рисою сучасної банківської справи $\epsilon$ те, що за формою та технологіями банківське обслуговування фізичних осіб все більше наближається до роздрібної торгівлі, ритейлу. Банки створюють клієнтоорієнтовану модель ведення бізнесу, пропонуючи специфічні види послуг специфічним групам клієнтів, намагаючись реалізувати принцип індивідуального обслуговування масової клієнтури. Зростає спроможність банків відзиватися на зміни та появу нових потреб споживачів. Таким чином, метою статтіє узагальнення та відображення основних теоретичних аспектів та розвитку банківського ритейлу 
A. Kuznyetsova, N. Kozmuk, I. Zherebylo, O. Sydorova, M. Zvarych. The Essence of Retail and Development of Retail Banking Innovative Mechanisms in Ukraine

в Україні, пошук шляхів оптимізації та збільшення обсягів продажу банківських продуктів і банківських послуг, забезпечення ведення ефективної маркетингової політики банку в сучасних умовах. Для розвитку банківського ритейлу банкам необхідно втримати депозитні вклади, запропонувавши вкладникам більш вигідні умови порівняно з іншими банками; нарощувати ресурсну базу за рахунок залучення депозитів населення. Виведено низку специфічних рис та особливостей банківського ритейлу, якими є: локальна асортиментна політика - полягає в потребі коригування портфеля банківських продуктів в залежності від місця розташування банківської установи; складність банківських послуг - вимагає від клієнтів певного освітнього рівня; необхідність підтримки особистої ліквідності кожного клієнта - без їі забезпечення стає неможливим ведення подальшої кредитної діяльності, забезпечення кругообігу коштів; індивідуалізація банківських послуг - полягає у врахуванні потреб і інтересів клієнтів банківської установи при формуванні пакету банківських послуг; диверсифікація банківських послуг - забезпечує як індивідуальний підхід до клієнта так і розширення спектру можливостей в виборі тих чи інших дій і перспектив. Крім того, в дослідженні наголошується на такій важливій складовій, як формування лояльності клієнта за рахунок: локаційного підходу до організації торгових точок; використання франчайзингової системи; спеціального угруповання асортименту; застосування спеціалізованого торгового обладнання; використання трейд-маркетингових технологій; вдосконалення форм розрахунків з покупцями; мінімального присутність торгового персоналу, пріоритету самообслуговування; автоматизації обліку, закупівель і зберігання товару; оптимізації діяльності логістичних структурних підрозділів та ін. Наведений перелік застосовуваних в статті технологій свідчить, що рітейл - це не тільки торгівля. Більшою мірою він являє собою особливу систему, в організаційному плані складається з посередницьких, логістичних, банківських структур, компаній оптової торгівлі. У процесі наукового дослідження використано методи логічного узагальнення і науковоі абстракції, статистичний метод, табличний метод (при відображенні особливостей традиційного банківського обслуговування та банківського ритейлу), схематичний метод (при відображенні основних трендів онлайн-ритейлу і переваг інноваційних технологій ведення банківського бізнесу) Результати дослідження дають підстави стверджувати, що для підвищення обсягів продажу банківських продуктів і банківських послуг, значну роль відіграє впровадження в діяльність банківських установ інноваційних заходів, що забезпечують новітні підходи до формування політики банківського ритейлу.

Ключові слова: бренд, імідж країни, конкурентоспроможність, стійкість, репутація країни.

Manuscript received: 04.11.2018

(c) The author(s) 2018. This article is published with open access at Sumy State University. 